Arq. Bras. Med. Vet. Zootec., v.66, n.5, p.1367-1375, 2014

\title{
Genes de virulência e diversidade genética em Salmonella spp. isoladas de amostras de origem suína
}

\author{
[Virulence genes and genetic diversity in Salmonella spp. isolated \\ from samples of swine origin] \\ M.S. Moura ${ }^{1}$, R.P. Oliveira ${ }^{1}$, R.T. Melo ${ }^{1}$, E.P. Mendonça ${ }^{1}$, B.B. Fonseca ${ }^{2}$, D.A. Rossi ${ }^{2}$ \\ ${ }^{1}$ Aluna de pós-graduação - Faculdade de Medicina Veterinária - Universidade Federal de Uberlândia, MG \\ ${ }^{2}$ Faculdade de Medicina Veterinária - Universidade Federal de Uberlândia - Uberlândia, MG
}

\begin{abstract}
RESUMO
A diversificação da produção industrial de alimentos de origem suína e o intercâmbio comercial de animais e seus derivados destinados ao consumo humano podem ser importantes disseminadores de sorovares de Salmonella spp. na cadeia alimentar. Objetivou-se avaliar em 86 cepas de Salmonella spp., isoladas em granja de terminação e no abate de suínos, a ocorrência de três genes de virulência (invA, agfA e lpfA), bem como a similaridade genética entre elas. A ocorrência do gene invA foi verificada em $100 \%$ das amostras. O gene lpfA foi detectado em $80,23 \%$ (69/86) das cepas, não foi detectado em $S$. Panama e estava presente em todas as cepas de $S$. Infantis. O gene agfA foi detectado em 63,95\% (55/86) das amostras. S. Agona apresentou positividade para todos os genes de virulência estudados. A análise de homologia entre as cepas agrupou os diferentes sorovares em clusters. A similaridade foi independente do local de isolamento, o que demonstra a presença de clones ao longo da cadeia de produção e a existência de multiplicidade de fontes para a infecção dos animais, como a ração, e a contaminação cruzada das carcaças. A pesquisa de genes de virulência e a avaliação da proximidade gênica permitem a caracterização e um maior entendimento sobre cepas de Salmonella circulantes na cadeia produtiva de suínos e, assim, podem subsidiar medidas de controle durante o processo produtivo com o objetivo de garantir a saúde do consumidor.
\end{abstract}

Palavras-chave: suíno, genes, RAPD-PCR, Salmonella, virulência

\begin{abstract}
The diversification of industrial food production of swine origin and trade of animals and their derivatives for human consumption may be important disseminators of serovars of Salmonella spp. in the food chain. This study aimed to evaluate 86 strains of Salmonella spp. isolated form in the finishing and slaughter of pigs, the occurrence of three virulence genes (invA, agfa and $\mathrm{lpfA}$ ), as well as the genetic similarity between them. The occurrence of gene invA was observed in 100\% of the samples. The gene lpfA was detected in 80.23\% (69/86) strains and is not detected in $\mathrm{S}$. Panama, but present in all strains of $\mathrm{S}$. Infantis. The gene agfA was detected in $63.95 \%$ (55/86). S. Agona was positive for all virulence genes studied. The analysis of homology between the different serovars grouped the isolates in clusters. The similarity was regardless of the location of isolation, demonstrating the presence of clones along the production chain and that there are multiple sources for the infection of animals, such as feed, and cross-contamination of carcasses. A survey of virulence genes and evaluation of gene proximity allow characterization and better understanding of Salmonella strains circulating in the pig production chain, thus being able to support control measures during the production process in order to ensure consumer health.
\end{abstract}

Keywords: swine, genes, RAPD-PCR, Salmonella, virulence

\section{INTRODUÇÃO}

A salmonelose é uma doença causada pela bactéria Salmonella, pertencente à família Enterobacteriaceae, na qual estão descritos mais de 2500 sorovares (Schaechter, 2009). Trata-se de um problema de saúde pública, devido à ampla distribuição na natureza e a seu caráter zoonótico, tanto em países desenvolvidos como em desenvolvimento (European..., 2009).

Recebido em 25 de abril de 2013

Aceito em 17 de dezembro de 2013

E-mail: marielasmoura@yahoo.com.br 
A diversificação da produção industrial de alimentos de origem suína e o intercâmbio comercial de animais e seus derivados destinados ao consumo humano podem ser importantes disseminadores de sorovares de Salmonella spp. na cadeia alimentar. Dessa forma, a presença desse microrganismo representa uma relevante barreira sanitária para o comércio de animais e seus subprodutos (Seixas et al., 2009).

A invasão de células do epitélio intestinal é um fator essencial de virulência no processo de infecção pela Salmonella spp. (D'Aoust e Maurer, 2007). A presença do gene invA indica uma eficiente entrada e invasão da Salmonella spp. no epitélio intestinal (Whang et al., 2009). Os operons fimbriais Salmonella específicos são essenciais para garantir a fixação e a patogenicidade desse agente. Neste estão incluídos o operon lpf (long polar fimbriae), que regula a expressão da fímbria polar longa (Folkesson et al., 1999) e o agf (aggregative fimbriae), envolvido na codificação das fímbrias e essencial na formação de biofilme (Gibson et al., 2007).

É amplamente aceito que os animais infectados com Salmonella são as maiores fontes de infecção para outros animais e seres humanos. Assim, é importante o monitoramento constante com identificação dos sorovares e estabelecimento da relação epidemiológica desses ao longo da cadeia de produção, por meio de técnicas moleculares que permitem investigar a permanência do agente (European..., 2008).

O presente estudo possuiu como objetivos avaliar em cepas de Salmonella spp. a presença dos genes de virulência invA, agfA e lpfA, bem como verificar a similaridade filogenética entre estas, como forma de determinar as possíveis fontes de infecção dos animais ou de contaminação das carcaças.

\section{MATERIAL E MÉTODOS}

Foram utilizadas 86 cepas de Salmonella spp., previamente isoladas e identificadas por Pacheco (2009), seguindo metodologia descrita pela ISO 6579 (2007). As cepas eram oriundas de três lotes diferentes de suínos, coletadas na granja de terminação e em um frigorífico sob inspeção oficial. Em cada coleta (lote), foi realizada amostragem de animais (fezes) na granja de terminação e na pocilga de espera do frigorífico, após o transporte dos animais. Durante o processo de abate, foram coletadas amostras em três pontos ( $s w a b s$ após depilação, linfonodos e swabs após evisceração), além de amostras ambientais (ração e swabs de arrasto na terminação e de equipamentos no abate). As cepas estudadas foram isoladas de amostras de todas as etapas (fezes, swabs de carcaças suínas, ambiente, linfonodos e ração). As Tab. 1 e 2 demonstram detalhes sobre a origem das cepas e os sorovares identificados em cada etapa.

As amostras previamente identificadas como Salmonella spp. e mantidas congeladas foram reativadas em caldo BHI (Brain Heart Infusion) (Difco®) durante 24 horas a $36^{\circ} \mathrm{C}$, posteriormente foi feita a extração e amplificação do DNA.

Para verificar se as cepas possuíam os genes de virulência invA, agfA e ipfA, foram utilizados os primers descritos na Tab. 3. As cepas de Salmonella Enteritidis (ATCC 13076) e Escherichia coli (ATCC 25922) foram utilizadas, respectivamente, como controles positivo e negativo.

A pesquisa de cada um dos genes de virulência foi realizada separadamente, e o processo de extração de DNA foi por lise térmica, de acordo com o descrito por Borsoi et al. (2009). As reações de PCR foram realizadas com um volume final de $25 \mu \mathrm{L}$, sendo $2 \mu \mathrm{L}$ de DNA template (DNA da amostra); $12,5 \mu \mathrm{L}$ de buffer mix 10x (10mM Tris-HCL pH 9,0; 50mM KCL); $2,0 \mu \mathrm{L}$ de DNTP mix $(250 \mu \mathrm{M}) ; 3,0 \mathrm{mM}$ de $\mathrm{MgCl}_{2} ; 1,75 \mathrm{U}$ de Taq DNA polimerase (Invitrogen $\left.{ }^{\circledR}\right)$ e $0,05 \mu \mathrm{L}$ de cada primer (20pmol) (Invitrogen $囚)$. As amostras foram submetidas à amplificação, composta por uma etapa de desnaturação a $94^{\circ} \mathrm{C}$ por cinco minutos, seguida de 35 ciclos $\left(94^{\circ} \mathrm{C}\right.$ por um segundo, $55^{\circ} \mathrm{C}$ por um segundo e $74^{\circ} \mathrm{C}$ por 21 segundos) e da extensão final a $72^{\circ} \mathrm{C}$ por sete minutos, com exceção do gene $\operatorname{agfA}$, cuja temperatura de anelamento foi de $58^{\circ} \mathrm{C}$. 
Tabela 1. Cepas de Salmonella spp. isoladas de suínos, discriminadas por coleta, tipo de amostra e local de coleta

\begin{tabular}{|c|c|c|c|c|c|}
\hline \multirow[b]{2}{*}{ Amostras coletadas } & \multicolumn{5}{|c|}{ Isolamentos } \\
\hline & Local de coleta & $\begin{array}{c}1^{\mathrm{a}} \\
\text { coleta }\end{array}$ & $\begin{array}{c}2^{\mathrm{a}} \\
\text { coleta }\end{array}$ & $\begin{array}{c}3^{\mathrm{a}} \\
\text { coleta }\end{array}$ & $\begin{array}{l}\text { Total } \\
\mathrm{P}(\%)\end{array}$ \\
\hline Fezes-swab retal $(\mathrm{n}=45)$ & Granja (terminação) & 9 & 9 & 7 & $25(29,07)$ \\
\hline Ração (n=3) & Granja (terminação) & 1 & 1 & 0 & $2(2,33)$ \\
\hline Água $(n=3)$ & Granja (terminação) & 0 & 0 & 0 & 0 \\
\hline$S w a b$ arrasto $(\mathrm{n}=3)$ & Granja (terminação) & 0 & 0 & 0 & 0 \\
\hline Fezes-swab retal $(\mathrm{n}=45)$ & Pocilga de espera & 7 & 8 & 7 & $22(25,58)$ \\
\hline Swab arrasto $(\mathrm{n}=3)$ & Pocilga de espera & 0 & 0 & 1 & $1(1,16)$ \\
\hline Carcaça após depilação $(n=45)$ & Frigorífico (abate) & 7 & 3 & 0 & $10(11,63)$ \\
\hline $\begin{array}{l}\text { Linfonodos cadeia mesentérica } \\
(\mathrm{n}=45)\end{array}$ & Frigorífico (abate) & 3 & 6 & 2 & $11(12,79)$ \\
\hline Carcaça após serragem $(n=45)$ & Frigorífico (abate) & 7 & 3 & 3 & $13(15,12)$ \\
\hline Swab superfície depiladeira $(\mathrm{n}=3)$ & Frigorífico (abate) & 0 & 0 & 1 & $1(1,16)$ \\
\hline Swab superfície serra $(\mathrm{n}=3)$ & Frigorífico (abate) & 1 & 0 & 0 & $1(1,16)$ \\
\hline$S w a b$ superfície faca $(\mathrm{n}=3)$ & Frigorífico (abate) & 0 & 0 & 0 & 0 \\
\hline Swab superfície mesa toalete $(\mathrm{n}=3)$ & Frigorífico (abate) & 0 & 0 & 0 & 0 \\
\hline Total $(n=249)$ & & 35 & 30 & 21 & $86(100)$ \\
\hline
\end{tabular}

n - número de amostras analisadas; $\mathrm{P}$ - amostras positivas para Salmonella spp.; \% - porcentagem de amostras positivas por amostra em relação ao total isolado. Compilado de Pacheco (2009).

Tabela 2. Sorovares de Salmonella isolados em granja de terminação, pocilga de espera e durante etapas do abate de suínos

\begin{tabular}{lcccc}
\hline Sorovar & $\begin{array}{c}\text { Granja de } \\
\text { terminação }\end{array}$ & $\begin{array}{c}\text { Pocilga de espera } \\
\text { (frigorífico) }\end{array}$ & $\begin{array}{c}\text { Etapas do abate } \\
\text { (frigorífico) }\end{array}$ & TOTAL \\
\hline S. Typhimurium & $\mathrm{N}(\%)$ & $\mathrm{N}(\%)$ & $\mathrm{N}(\%)$ & $\mathrm{N}(\%)$ \\
S. Agona & $8(9,30)$ & $5(5,81)$ & $15(17,44)$ & $28(32,56)$ \\
S. Infantis & $9(10,46)$ & $6(6,98)$ & $5(5,81)$ & $20(23,25)$ \\
$S$. Minnesota & $4(4,65)$ & $5(5,81)$ & $8(9,30)$ & $17(19,77)$ \\
$S$. Panama & $6(6,98)$ & $6(6,98)$ & $3(3,49)$ & $15(17,44)$ \\
\hline Total & -- & $1(1,16)$ & $5(5,81)$ & $6(6,98)$ \\
\hline
\end{tabular}

$\mathrm{N}(\%)$ - número de amostras positivas de cada sorovar e porcentagem em relação ao total de amostras identificadas como Salmonella spp. Compilado de Pacheco (2009).

Tabela 3. Sequência de primers utilizados para a reação de PCR e referência bibliográfica

\begin{tabular}{|c|c|c|c|}
\hline Gene & Primer & Tamanho $(\mathrm{pb})$ & Referência bibliográfica \\
\hline $\operatorname{inv} A$ & $\begin{array}{l}\text { F:5'gtgaaattatcgccacgttcgggcaa3' } \\
\text { R:5'tcatcgcaccgtcaaaggaacc3' }\end{array}$ & 284 & Oliveira et al. (2002) \\
\hline $\operatorname{agfA}$ & $\begin{array}{l}\text { F:5'tccacaatggggcggcggcg3' } \\
\text { R:5'cctgacgcaccattacgctg3' }\end{array}$ & 350 & Collinson et al. (1992) \\
\hline $\operatorname{lpfA}$ & $\begin{array}{l}\text { F:5'ctttcgctgctgaatctggt } 3 \text { ', } \\
\text { R:5'cagtgttaacagaaaccagt } 3 \text { ' }\end{array}$ & 250 & Bäumler e Heffron (1995) \\
\hline
\end{tabular}

F: forward; R: reverse; pb: pares de bases.

Para avaliação da similaridade genética entre as cepas de Salmonella, foi realizado RAPD-PCR (Random Amplified Polymorphic DNA), utilizando-se o primer P1254 (5' CCGCAGCCAA 3'), recomendado por Oliveira et al. (2002). A reação de PCR foi realizada com um volume final de $25 \mu \mathrm{L}$ por amostra, contendo $100 \mathrm{mmol}$ Tris $\mathrm{HCl}, 750 \mathrm{mmol} \mathrm{KCl} \mathrm{pH} 8,8$, $10 \mathrm{mmol}$ dNTPs $(5 \mathrm{mmol}$ de cada - dATP, dCTP, dGTP e dTTP), 50mmol $\mathrm{MgCl}_{2}$, 40pmol do primer, $1 \mathrm{U}$ de Taq DNA Polymerase $5 \mathrm{U} / \mu \mathrm{L}$ (Invitrogen®) e 30ng de DNA. A reação PCR foi 
conduzida dentro das seguintes condições: um ciclo de $95^{\circ} \mathrm{C}$ por cinco minutos, seguido de 40 ciclos $\left(95^{\circ} \mathrm{C}\right.$ por um minuto, $30^{\circ} \mathrm{C}$ por um minuto e $72^{\circ} \mathrm{C}$ por um minuto) e da extensão final a $72^{\circ} \mathrm{C}$ por cinco minutos.

Todas as reações de PCR foram realizadas no termociclador (Eppendorf®) em triplicata, e os produtos amplificados separados por eletroforese em gel de agarose a 1,5\% por 90 minutos, com utilização do marcador de peso molecular de 100pb (Invitrogen ${ }^{\circledR}$ ). O gel foi corado com Syber Safe (Invitrogen $\left.{ }^{\circledR}\right)$ e visualizado em luz ultravioleta em transiluminador (Loccus Biotecnologia $\left.{ }^{\circledR}\right)$.

Os resultados obtidos foram tabulados e submetidos à estatística descritiva, com cálculo das porcentagens de positividade para os genes de virulência estudados. As análises dos géis obtidos pela RAPD-PCR foram realizadas utilizando-se o coeficiente de similaridade de Dice, com tolerância de $1,5 \%$ na comparação da posição de bandas e o dendograma formado com base no método UPGMA (Unweighted Pair Group Method with Arithmetic Mean agrupamento pareado não ponderado baseado na média aritmética). Esses procedimentos e a construção do dendograma foram realizados com o software GelCompar.

\section{RESULTADOS E DISCUSSÃO}

Em $100 \%$ das cepas de Salmonella spp. foi detectado o gene invA. Estudos realizados no Brasil por Castilla (2003), em carne de frango, e por Lopes (2011), em carne bovina, para a verificação da ocorrência do gene invA em amostras de Salmonella spp., mostraram 100\% de positividade em 120 amostras e 95,5\% em 44 amostras, respectivamente. De acordo com Whang et al. (2009), o gene invA parece ser conservado em todos os sorovares de Salmonella spp. e, por isso, é utilizado como gene-alvo para a detecção da bactéria pela técnica da PCR.

O gene agf A foi detectado em 55/86 (63,95\%) das cepas, com $100 \%$ de positividade nos sorovares S. Minnesota e S. Agona (Fig. 1). Outras pesquisas detectaram o gene agfA em $100 \%$ de amostras provenientes de material avícola (Cesco, 2010; Galdino, 2010). Borsoi et al. (2009) encontraram este mesmo gene em $91,4 \%$ de 32 cepas isoladas de aves, resultado que se diferencia da quantidade encontrada no presente estudo.

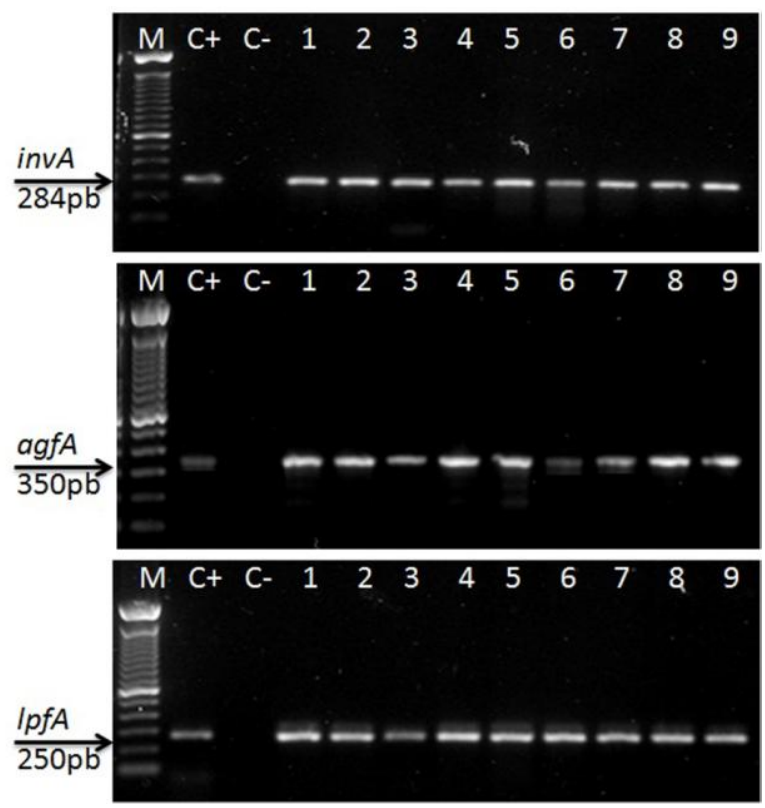

Figura 1. Genes invA, agfA e lpfA em S. Agona. M (Marcador-100pb), C+ (controle positivo Salmonella Enteritidis ATCC 13076), C- (controle negativo Escherichia coli ATCC 25922), 1-9 (amostras positivas para os genes invA, agfA e lpfA). 
O gene lpfA foi detectado em 69/86 (80,23\%) das cepas analisadas. Nenhuma das seis cepas do sorovar Panama apresentou positividade para este gene, mas todas as 17 cepas do sorovar Infantis possuíam este gene. Cesco (2010) relatou a presença do gene lpfA em $100 \%$ das 45 amostras isoladas de mecônio, carcaças e cortes de frango no Rio Grande do Sul. Em trabalho realizado nos estados de São Paulo e Paraná, Galdino (2010) relatou que os genes lpfA e invA estavam presentes em $94,4 \%$ das 18 cepas isoladas de swabs de arrasto provenientes de aviários de frango de corte.

Entre as 86 cepas analisadas, $47(54,65 \%)$ possuíam os três genes estudados, $30(37,04 \%)$ dois genes e nove $(11,11 \%)$ apresentaram positividade para apenas um gene. Todas as 20 cepas de $S$. Agona apresentaram positividade para os três genes de virulência estudados, seguido de $S$. Minnesota, com 73,34\% (11/15); $S$. Infantis, com 58,82\% (10/17), e de $S$. Typhimurium, com $28,57 \%$ (8/28), mas nenhuma das seis cepas de $S$. Panama apresentou positividade para todos os genes simultaneamente.

A associação entre sorotipos virulentos de Salmonella que rotineiramente produzem doença sistêmica e a presença de plasmídeos de alto peso molecular são relatadas na literatura (Barrow e Lovell, 1988). Tanto S. Agona quanto $S$. Derby têm sido relatados como sorovares relacionados à doença clínica em suínos, que tem aumentado significativamente, sobretudo nos Estados Unidos (Oliveira e Carvalho, 2003). As elevadas porcentagens de genes de virulência encontrados para os sorovares $S$. Agona e $S$. Infantis representam riscos de casos de salmonelose, já que estes sorovares, assim como $S$. Typhimurium e $S$. Enteritidis, são os mais associados à doença em humanos no Brasil (Loureiro et al., 2010). S. Infantis e $S$. Agona também são reconhecidos por seu potencial patogênico, o qual, além do quadro gastroentérico, pode determinar infecção septicêmica nos animais jovens e no homem, bem como outros casos de infecções graves em crianças (Tessmann et al., 2008).

A homologia entre cepas pertencentes a um mesmo sorovar é demonstrada na Fig. 2 pelos agrupamentos em dendogramas.
A análise dos dendogramas demonstrou as porcentagens de similaridade entre as cepas que foram agrupadas em clusters. Os resultados mostram que a similaridade entre as cepas de um mesmo sorovar foi independente do local de isolamento, ou seja, de carcaças ou fezes, com exceção do sorovar Panama, no qual se observou que o grupo $\mathrm{J}$ continha cinco cepas provenientes de carcaça e uma amostra proveniente de fezes com perfil distinto (Fig. 2e).

Foram discriminados quatro clusters (A, B, C e D), contendo cinco grupos de clones, e três cepas apresentaram perfil distinto em $S$. Typhimurium, todas da primeira coleta, porém com similaridade maior que $80 \%$ com pelo menos um dos clones (Fig. 2a). Os resultados indicam que a presença de $S$. Typhimurium nas fezes dos animais contribui para a contaminação da carcaça após o abate, o que demonstra que medidas de controle no campo, se eficientes na redução da presença desse sorovar no conteúdo intestinal dos animais, também auxiliam na diminuição dele durante as etapas de abate e, consequentemente, no risco de infecção de humanos

$S$. Agona foi agrupada em dois grupos clonais distintos, com similaridade de $78,7 \%$ entre eles (E e F), um com quatro e outro com 16 cepas, provenientes da primeira e segunda coletas (Fig. 2b). Apesar de esse sorovar ter sido isolado tanto de animais vivos como de carcaças, não foi identificado após evisceração. É provável que as condições de processamento pós-abate tenham limitado sua sobrevivência e multiplicação, e isso explica, em parte, sua ausência nas carcaças após a serragem.

Das amostras ambientais, $S$. Typhimurium e $S$. Agona foram isoladas de ração na primeira e segunda coletas, respectivamente. A análise do dendograma indica que possivelmente esta foi a fonte de infecção dos animais na granja de terminação, pois $S$. Typhimurium isolada da ração apresentou homologia de $92,3 \%$ com sete amostras isoladas de fezes (A) (Fig. 2a). No caso do sorovar Agona, a amostra de ração está inserida no perfil $\mathrm{F}$, grupo clonal, com mais 15 cepas, sendo 11 provenientes de fezes (Fig. 2b). A importância da ração como forma de infecção de suínos corrobora resultados de estudos de alguns pesquisadores (Kich et al., 2005; Silva et al., 2006). 


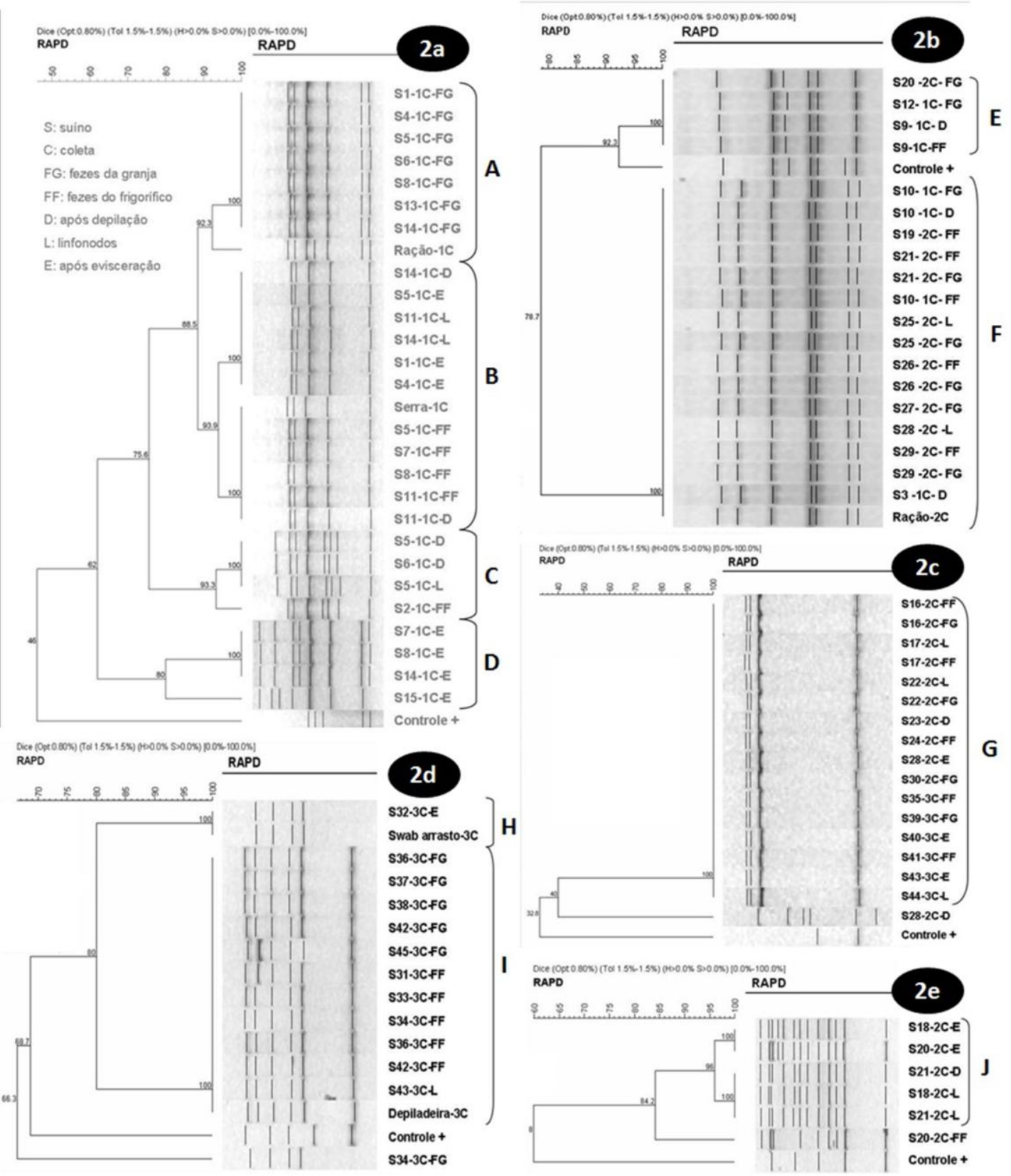

Figura 2. Dendogramas dos 86 cepas de Salmonella discriminados por sorovar. (2a) S. Typhimurium. (2b) $S$. Agona. (2c) $S$. Infantis. (2d) $S$. Minnesota. (2e) $S$. Panama. (S) suíno, (C) coleta, (FG) isolados de fezes dos animais na granja, (FF) isolados de fezes dos animais no frigorífico, (D) etapa após depilação, (L) linfonodos, (E) etapa após evisceração.

A classificação dentro de um mesmo grupo clonal de $S$. Agona isolados de fezes de lotes sucessivos de animais alojados na granja (primeira e segunda coletas) sugere negligência às normas de biosseguridade, o que pode contribuir para a manutenção do microrganismo no ambiente. Porém, esse comportamento não se repetiu para $S$. Typhimurium, o mais prevalente na primeira coleta. Assim, é possível que os animais amostrados já estivessem infectados com $S$. Agona em etapas de criação anteriores, como desmame e creche. Essa hipótese está de acordo com estudo de Müller et al. (2009), os quais relataram que, entre as fontes mais 
importantes de infecção dos animais por Salmonella na produção de suínos, podem ser destacados o alojamento de animais portadores que sofreram a infecção na fase de creche e a contaminação residual das instalações.

A alta porcentagem de cepas de $S$. Typhimurium durante todas as etapas de abate corrobora o fato de este ser o sorovar mais isolado em alimentos de origem suína no Brasil (Spricigo et al., 2008). Já para o sorovar Agona, apesar de ser o segundo mais frequente neste estudo, a positividade concentrou-se nas amostras de fezes, com baixo isolamento durante as etapas de abate.

A contaminação cruzada também parece ser importante na disseminação de $S$. Typhimurium ao longo da cadeia de produção. A cepa isolada na serra pertence ao mesmo grupo clonal que quatro cepas de fezes coletadas de animais alojados na pocilga do frigorífico e apresenta similaridade de $93,9 \%$ com outro grupo clonal, que envolve seis cepas isoladas de amostras coletadas após depilação, em linfonodos ou na carcaça após evisceração, inserido no cluster B.

A maior similaridade entre as cepas foi observada para $S$. Infantis, com 16 isoladas na segunda e terceira coletas pertencentes a um mesmo grupo clonal $(G)$. A exceção foi uma cepa com perfil distinto, isolado do suíno 28, que era proveniente da segunda coleta (Fig. 2c).

É possível que a presença do sorovar Infantis nas amostras de fezes esteja relacionada à contaminação ambiental na granja ou à infecção dos animais em etapas anteriores à terminação, já que os isolados da segunda e terceira coletas pertencem ao mesmo grupo clonal. Porém, esse sorovar não foi isolado no swab de arrasto realizado na granja que alojava os animais.

$S$. Minnesota apresentou dois grupos clonais $(\mathrm{H}$ e I) com similaridade de $80 \%$, um agrupando 12 cepas e outro duas. Uma cepa apresentou padrão distinto das demais (Fig. 2d). Entre as seis amostras ambientais da segunda coleta, esse sorovar foi identificado em duas ocasiões, uma de $s w a b$ de arrasto da pocilga no frigorífico e uma da superfície da depiladeira. A homologia de $100 \%$ da amostra isolada na superfície da depiladeira com 10 cepas de fezes (I) demonstra que a infecção dos animais é a fonte de contaminação do ambiente do abate. Porém, o número de isolamento desse sorovar foi baixo nas carcaças, com positividade somente em uma amostra de linfonodo (suíno 43) e uma de carcaça após evisceração (suíno 32). Isto sugere que, apesar da boa adaptação ambiental que permite sua permanência no ecossistema, o perfil que englobou o maior número de cepas desse sorovar não permanece nas carcaças ou sofre injúria durante o processo de abate e, assim, mantém-se em números não detectáveis na técnica de isolamento tradicional utilizada neste estudo.

Outra hipótese para explicar o baixo número de isolamentos de $S$. Minnesota nas etapas de abate é a possibilidade de que algum evento especificamente ligado à terceira coleta tenha influenciado nos resultados, como o número de animais abatidos, a ordem de abate dos animais amostrados em relação aos demais ou mudanças dos procedimentos internos. Não houve controle neste trabalho com relação a esses eventos ou informação sobre mudanças na concentração de cloro da água de lavagem ou quantidade/tipo de agentes químicos utilizados para a limpeza e desinfecção. Assim, não foi possível determinar se houve alguma mudança nos procedimentos em relação aos outros procedimentos de abate.

As seis cepas identificadas como $S$. Panama formaram um cluster com $96 \%$ de similaridade (J), e uma cepa não foi agrupada em nenhum deles. Todas as cepas eram provenientes da segunda coleta. Das seis cepas, somente uma foi proveniente de fezes (suíno 20) e apresentou $84,2 \%$ de homologia com as demais. Tais resultados demonstram que a contaminação da carcaça por esse sorovar durante as etapas de abate provavelmente não esteja relacionada à infecção prévia dos animais (Fig. 2e).

Os sorovares Infantis e Panama, mais isolados nas amostras de carcaças na segunda coleta, segundo a Anvisa, estão incluídos entre os sorotipos mais frequentemente identificados em amostras humanas oriundas de surtos de doenças transmitidas pelos alimentos no Brasil (Rodrigues, 2005). Spricigo et al. (2008) relatam que $S$. Panama, $S$. Agona e $S$. Infantis foram os sorovares mais identificados em amostras de linguiça suína em Santa Catarina, fato que demonstra a importância destes sorovares na saúde pública. 
Ao se avaliar a presença de genes de virulência, constatou-se que os clusters E e F de $S$. Agona e $\mathrm{H}$ de $S$. Minnesota foram compostos por cepas que apresentaram genes em comum, o que evidenciou, mais uma vez, a elevada proximidade filogenética. Essa correlação também representa um dado importante na investigação epidemiológica da identificação de grupos de cepas com maior potencial patogênico.

Os clusters E, F, G, H, I englobaram a maioria das cepas que possuíam todos os genes de virulência estudados. Já os grupos clonais A, B, $\mathrm{C}$ e $\mathrm{D}$, todos de $S$. Typhimurium, foram compostos por cepas que possuíam principalmente o gene lpfA. O grupo J de $S$. Panama apresentou três cepas com o gene agfA, e as demais somente o $\operatorname{inv} A$, gene comum a todas as cepas do estudo.

Os resultados obtidos neste estudo reforçam a necessidade de monitoramento da presença de Salmonella na criação de suínos. Indicam também que o monitoramento e o controle devem acontecer em todas as etapas de produção até o abate, pois diferentes fatores parecem influenciar a permanência ou não de determinados sorovares na carne produzida.

\section{CONCLUSÕES}

A presença de todos os genes de virulência em $54,65 \%$ das cepas avaliadas atenta para o risco de doença clínica tanto em suínos quanto em humanos. S. Agona representa o sorovar com o maior número de genes relacionados à virulência. A relação filogenética entre as cepas indicou que o consumo de ração contaminada é uma possível fonte de infecção dos animais pelos sorovares Agona e Typhimurium e que a contaminação cruzada contribuiu para a disseminação de $S$. Typhimurium durante as etapas de abate, o que aumenta o risco de contaminação da carne e de infecções em humanos.

\section{REFERÊNCIAS}

BARROW, P.A.; LOVELL, M.A. The association between a large molecular mass plasmid and virulence in a strain of Salmonella Pullorum. J. Gen. Microbiol., v.134, p. 23072316, 1988.
B ÄUMLER, A.J.; HEFFRON, F. Identification and sequence analyses of lpfabcde, A putative fimbrial operon of Salmonella Typhimurium. J. Bacteriol., v.177, p.2087-2097. 1995.

BORSOI, A.; SANTIN, E.; SANTOS, L.R. et al. Inoculation of newly hatched broiler chicks with two Brazilian isolates of Salmonella Heidelberg strains with different virulence gene profiles, antimicrobial resistence, and pulse field gel electrophoresis patterns to intestinal changes evaluation. Poultry Sci., v.88, p.750-758, 2009.

CASTILLA, K.S. Detecção de genes de virulência em diferentes fagotipos e ribotipos de Salmonella Enteritidis utilizando a reação em cadeia da polimerase (PCR). 2003. 77f. Dissertação (Mestrado) - Faculdade de Medicina Veterinária e Zootecnia, Universidade de São Paulo, São Paulo.

CESCO, M.A.O. Pesquisa de fatores associados a virulência de Salmonella Hadar através da Reação em Cadeia da Polimerase (PCR). 2010. 85f. Dissertação (Mestrado em Ciências Veterinárias) - Faculdade de Veterinária, Universidade Federal do Rio Grande do Sul, Porto Alegre.

COLLINSON, S.K.; EMODY, L.; TRUST, T.J. et al. Thin aggregative fimbriae from diarrheagenic Escherichia coli. J. Bacteriol., v.174, p.4490-4495, 1992.

D’AOUST, J.Y.; MAURER, J. Salmonella species. In: DOYLE, M.P.; BEUCHAT, L.R. (Ed). Food Microbiology: Fundamentals and Fontiers. Washington: ASM Press, 2007.

EUROPEAN Food Safety Authority - Scientific Opinion of the Panel on Biological Hazards on a request from the European Food Safety Authority on foodborne antimicrobial resistance as a biological hazard. The EFSA Journal. Italy, n.765, p.1-87, 2008.

EUROPEAN Food Safety Authority - The Community Summary Report on Trends and Sources of Zoonoses and Zoonotic Agents in the European Union in 2007, The EFSA Journal. Italy, p.223, 2009.

FOLKESSON, A.; ADVANI, A.; SUKUPOLVI, S. et al. Multiple insertions of fimbrial operons correlate with the evolution of Salmonella serovars responsible for human disease. Mol. Microbiology, v.33, p.612-622,1999. 
GALDINO, V.M.C.A. Pesquisa de genes de virulência e antibiograma em Salmonella spp. de origem avícola. 2010. 55f. Monografia (Especialização em Ciência Avícola) Faculdade de Medicina Veterinária, Universidade Federal de Uberlândia, Uberlândia.

GIBSON, D.L.; WHITE, A.P.; RAJOTTE, C.M. et al. AgfC and AgfE facilitate extracellular thin aggregative fimbriae synthesis in Salmonella Enteritidis. Microbiology Sgm, v.153, p.11311140, 2007.

ISO 6579. Microbiology of food and animal feeding stuffs - Horizontal method for the detection of Salmonella spp., 4ed, 2002. The International Organization for Standardization, 2007.

KICH, J.D.; MORES, N.; PIFFER, I.A. et al. Fatores associados à soroprevalência de Salmonella em rebanhos comerciais suínos. Cienc. Rural, v.35, p.398-405, 2005.

LOPES, J.T. Salmonella spp na cadeia de produção de carne bovina de exportação: ocorrência, perfil de susceptibilidade antimicrobiana, genes de virulência e perfil de macrorrestrição por PFGE. 2011. $98 \mathrm{f}$. Dissertação (Mestrado) - Faculdade de Ciências Farmacêuticas, Universidade de São Paulo, São Paulo.

LOUREIRO, E.C.B.; MARQUES, N.D.B.; RAMOS, F.L.P. et al. Salmonella serovars of human origin identified in Pará state, Brazil from 1991 to 2008. Rev. Pan-Amazonica Saude, v.1, p.93-100, 2010.

MÜLLER, M.; SCHWARZ, P.; KICH，J.D; CARDOSO, M.R.I. Perfil sorológico e de isolamento de Salmonella sp. sm suínos no início da terminação e ao abate. Cienc. Anim. Bras., v.10, p.931-937, 2009.

OLIVEIRA, C.J.B.; CARVALHO, L.F.O.S. Infecções por Salmonella em suínos: panorama e perspectivas. Suinocultura Indust., v.3, p.35-39, 2003.
OLIVEIRA, S.D.; SANTOS, L.R.; SCHUCH, D.M.T. et al. Detection and identification of Salmonella from poultry related samples by PCR. Vet. Microbiol., v.87, p.25-35, 2002.

PACHECO, M.T.N. Salmonella sp. em rebanho comercial de suínos e em suas carcaças processadas no frigorífico. 2009. 69f. Dissertação (Mestrado em Ciências Veterinárias) - Universidade Federal de Uberlândia, Uberlândia.

RODRIGUES, D.P. Vigilância de Salmonella. In: Capacitação e Controle de Salmonella WHO - Global Salmonella Surveillance. Aula ministrada na FIOCRUZ, Rio de Janeiro, 26 set. 2005.

SCHAECHTER, M. Desk Encyclopedia of Microbiology. 2.ed, 2009. p.415-416.

SEIXAS, F.N.; TOCHETTO, R.; FERRAZ, S.M. Presença de Salmonella spp. em carcaças suínas amostradas em diferentes pontos da linha de processamento. Cienc. Anim. Bras., v.10, p.634-640, 2009.

SILVA, L.E.; GOTARDI, C.; VIZZOTTO, R. et al. Infecção por Salmonella sp. em um sistema integrado de produção de suínos. Arq. Bras. Med. Vet. Zootec., v.58, p.455-461, 2006.

SPRICIGO, D.A.; MATSUMOTO, S.R.; ESPÍNDOLA, M.L. et al. Prevalência e perfil de resistência a antimicrobianos de sorovares de Salmonella isolados de lingüiças suínas tipo frescal em Lages, SC. Arq. Bras. Med. Vet. Zootec., v.60, p.517-520, 2008.

TESSMANN, C.; ZOCCHE, F.; LIMA, A.S. et al. Ocorrência e Perfil de sensibilidade a antibióticos de Salmonella spp isolada em cortes de carne suína comercializados em feiras livres de Pelotas (RS). Bol. Centro de Pesq. de Proce. de Alim., v.26, p.307-313, 2008.

WHANG, Y.P.; LIA, L.; SHENA, J.Z. et al. Quinolone-resistance in Salmonella is associated with decreased mRNA expression of virulence genes invA and $a v r A$, growth and intracellular invasion and survival. Vet. Microbiol., v.133, p.328-334, 2009. 